\title{
Earnings announcement lag and non-mandatory disclosure impact on the cost of debt: Hong Kong empirical evidence
}

\author{
Achraf Guidara $^{a^{*}}$ and Imen Achek ${ }^{\mathrm{b}}$
}

${ }^{a}$ Assistant professor, Faculty of Economics and Management of Sfax, University of Sfax, Tunisia ${ }^{b}$ PhD Student, High School of Commerce of Tunis, University of Manouba, Tunisia

\begin{tabular}{l}
\hline C H R O N I C L E \\
\hline Article history: \\
Received September 18, 2014 \\
Accepted 17 December 2014 \\
Available online \\
December 232014 \\
\hline Keywords: \\
Cost of debt \\
Extent of voluntary disclosure \\
Earning announcement lag \\
Hong Kong
\end{tabular}

\section{Introduction}

Voluntary disclosure and earnings announcements are still catching too much interest in accounting literature (Lee et al. 2008; Bowrin, 2008). The economic crisis that hits several developed and developing countries highlights the importance of disclosure quality in gaining market confidence. Researches on the economic consequences of disclosure and earnings announcement represent a well defined research area in developed countries such as the USA and Europe. (Cooke, 1989; Meek \& Gray, 1989; Meek, Roberts, \& Gray, 1995). However, few empirical investigations in this regard have been conducted in emergent economies. Countries like Hong Kong present a very interesting setting to study. The WEF's Global Competitiveness Report ${ }^{1}$ reports that (p. 70) "Hong Kong was judged to have the most developed financial market in the world. Financial services in the region are some of the most 
available and affordable in the world". Thus, Hong Kong is one of the best economies in the world according to the World Economic Forum's Global Competitiveness Report.

Recent years, several companies have been privatized in Asia. Therefore, moving from a centralized economy ruled by high interventionism from the government to open market economy (case of China), will certainly put pressure on companies to disclose more. Companies are certainly aware that voluntary disclosure and timely announcement of earnings will have an impact on reducing stakeholders' uncertainty, improve competitiveness and expected returns, which will have in return impact on growth and value creation (Gray et al., 1995, Meek \& Gray, 1989). Therefore, Honk Kong is worthy of study for several reasons. First, there has been limited empirical evidence with respect to the association between voluntary disclosure, earning announcement lag and cost of debt since the pioneering work of Sengupta (1998). Following, such topic has attracted a great deal of attention in empirical literature (Anil \& Jonathan, 2003).

Second, such relationship remains under researched in emerging and developing economies where financial institutions play a critical role in financing companies' activities. This is particularly true for Hong Kong. For instance, Jang and Tang (2003, p. 25), "The banking sector plays an important role in the service-based economy of Hong Kong". They add that "The banking sector provides worldwide services that enhance the international financial status of Hong Kong". Under a financial approach and with the objective of maximizing the firm value by reducing information asymmetry between investors, creditors and management of the company (Healy \& Palepu, 2001), managers have more incentives to reveal voluntarily information in timely way. Therefore, the question is whether firms profit from additional disclosures by reducing the cost of debt? Results show that the extent of voluntary and earnings announcement lag are negatively associated with the cost of debt in Hong Kong. Our paper contributes to the literature dealing with the economic consequences of disclosure policy on cost of

finance by focusing on Hong Kong setting. Our paper highlights, on the one hand, the importance of increasing the extent of voluntary information in reducing information asymmetry and agency costs between companies and creditors. On the other hand, communicating earnings in early time can increase quality of disclosure in financial market (Blanchet, 2002). Therefore, managers, in Hong Kong setting, will have more incentives to increase the quality of voluntary disclosure to reduce their cost of debt.

The remainder of this paper is organized as follows. Section 2 reviews prior studies and develops the hypotheses. Section 3 describes our method, sample, and data. Section 4 reports and discusses the results and finally section 5 concludes and offers lines for future research.

\section{Literature review and hypotheses development}

To develop our research hypotheses, we review previous research, which suggests there is an association between voluntary disclosure, earnings announcement lag and cost of debt. We formulate hypotheses with regard to disclosure, earnings announcements lag and the cost of debt.

\subsection{The extent of voluntary disclosure and the cost of debt}

There is an extensive literature with regard to the relationship between voluntary disclosure and cost of debt. The availability of sufficient information may increase the opportunity to get external finance with lower costs (Armitage \& Marston, 2007). Higher level of voluntary disclosure lowers the cost of debt capital since it reduces the information asymmetry between management and creditors (Healy \& Palepu, 2001; Bhojraj \& Sengupta, 2003). Voluntary disclosure can influence lenders decisions, which in turn, affect the cost of financing (Jensen \& Meckling, 1976). In order to increase the quality of reporting, managers communicate voluntary information in the annual reports to justify their efforts to the stakeholders (e.g. Epstein \& Birchard, 2000; Gray, 2002). Sengupta (1998) investigates the 
relationship between the quality of information disclosure and cost of debt for a sample of US listed companies. She finds a negative relationship between financial costs and disclosure quality. Sengupta's finding supports the argument that lenders (banks) consider firms' disclosure quality in their default risk estimates. Increasing disclosure levels are perceived to have a lower default risk and consequently a lower cost of borrowing. As a result, companies that report more voluntary information in their annual reports will get a lower rate of interest when contracting with banks. Klai and Omri (2011) argue that the high debt ratio is related to the better information quality the creditors require more disclosure from the companies to guarantee the repayment of debts.

In addition, Dadashi et al. (2013) have studied the association between information voluntary disclosure and cost of debt in an Asian setting namely Iran. Results indicate that there is no relationship between the amount of information voluntary disclosure and cost of debt. However, Wang et al. (2008) find in China that companies benefit from an extensive voluntary disclosure by having a lower cost of debt.

Highly geared company has a greater obligation to satisfy the needs of long-term creditors for information (Wallace et al., 1994). From the perspective of signaling theory, Akerlof (1970) argues that lower-geared companies may wish to draw attention to their financial structure by communicating more voluntary disclosure.

In summary, the full and proper disclosure of voluntary information to investors and creditors will cause to create symmetric information or the same opportunities to access information for them (see figure 1). With reference to previous literature, the first hypothesis of this research is the following:

\section{$H_{1}$ : There is a negative association between voluntary disclosure and the cost of debt in Hong Kong.}

\subsection{Earnings announcement lag and the cost of debt}

One of the characteristics of financial information is its timeliness. The information is expected to lose its relevance if it comes not in time. FASB's statement (1980) defines timeliness as an important factor affecting one of the qualitative characteristics of financial statements' relevance. The time of disclosing earnings is an important topic in the accounting literature. Market interprets the disclosure or the nondisclosure and reacts accordingly. Earnings disclosure mitigates the adverse selection problem and reduces the information asymmetry which may reduce the cost of debt (Diamond \& Verrechia, 1991).

In this study, earnings announcement lag is measured in terms of the lapse of time between a companies' fiscal year-end and the date when financial statements are certified by auditor (Leventis \& Owusu-Ansah, 2006). Prior studies reported timely information is very important (see, for example, Chambers \& Penman, 1984; Begley \& Fischer, 1998). Similar results are found by Chambers and Penman (1984) and Begley and Fischer (1998) who conclude that firms accelerate the release of good news and delay the disclosure of bad news. We also observe a significant price reaction to the annual earnings announcements for both early (good news) and late (bad news) reporting firms. Their studies document that managers who publish early their annual reports increase the accuracy of earnings forecasts among creditors and investors.

Communicating information in early way is a signal of transparency and quality of financial reporting. According to Kulzick (2004, p 12) "transparency from the users' perspective includes the following eight concepts: accuracy, consistency, appropriateness, completeness, clarity, convenience, and timeliness". Bowrin (2008) suggests that financial reporting quality derives from the two qualitative characteristics: relevance and reliability. According to Bowrin, relevance is strictly related to the information's ability to affect users' decision making and timeliness is one part of relevance. Entwistle and Phillips (2003) shows that earnings quality is defined as earnings' ability to provide useful information for evaluating future cash flows. This figure gives more explanation for the usefulness of early reporting to increase both the relevance and the reliability of financial reporting quality. 
Understandability

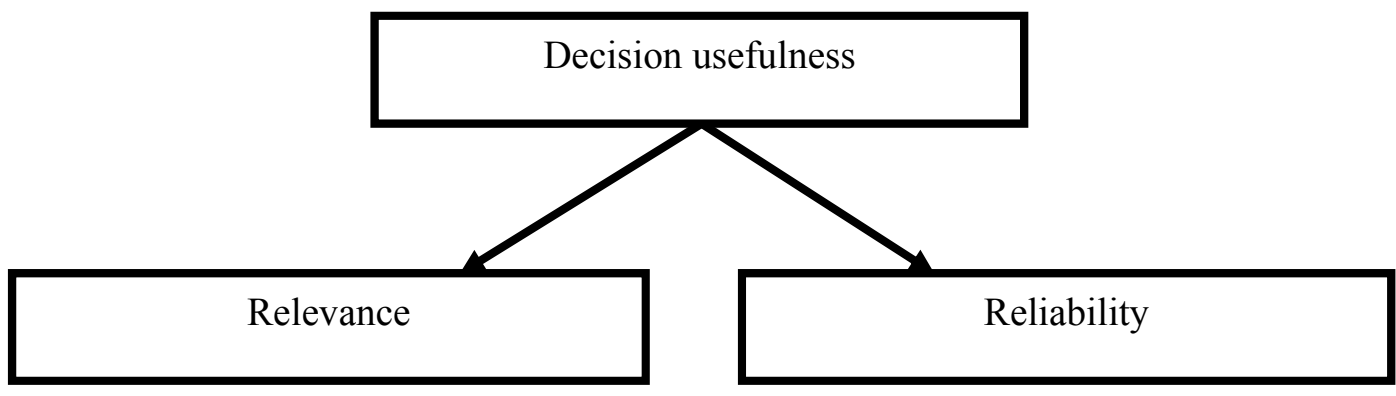

Fig. 1. Financial reporting quality

Finally, a study of the relationship between earning announcement lag and cost of debt will add more insight on the importance of early disclosure in solving firstly, agency problems between lenders (banks) and managers and secondly in reducing the cost of debt capital, especially in an active financial market such as the Hong Kong Stock Exchange. Given the lack of evidence in Asian markets and the ambiguous empirical evidence in some developed countries, and based the above theoretical predictions, we hypothesize that:

\section{$\mathrm{H}_{2}$ : There is a positive and significant association between earnings announcement lag and cost of debt} in Hong Kong.

\section{Research method}

\subsection{Sample and data collection}

The sample of this study is drawn from listed companies in the Hong Kong Stock Exchange. Annual reports from 2008 to 2011 were analyzed. Hong Kong is a very interesting setting to study. Hong Kong is major financial hub for south-east Asia; it was named the world's top financial center for the second year running by the World Economic Forum (WEF), thanks to the strength of its business environment, infrastructure and a favorable tax regime. Our sample consists only of non-financial firms. These firms were excluded due to the particular regulatory requirements for this sector. Based on random selection sampling, 20 firms were selected yielding a total number of 80 firm-year observations. Companies are spread across five sectors (mining, retail, industrial, chemicals and services).

\section{Table 1}

Sample description

\begin{tabular}{ccccccc}
\hline & & Hong Kong & & Total \\
\hline Years & Mining & Retail & Industrial & Chemicals & Services & \\
\hline 2008 & 2 & 1 & 5 & 4 & 8 & 20 \\
2009 & 2 & 1 & 5 & 4 & 8 & 20 \\
2010 & 2 & 1 & 5 & 4 & 8 & 20 \\
2011 & 2 & 1 & 5 & 4 & 8 & 20 \\
\hline
\end{tabular}


Variables are based on previous literature. Table 2 summarizes the variables used in our model. Data was collected from companies' annual reports downloaded from the official website and the Hong Kong Exchange.

Table 2

Data sources

\begin{tabular}{|c|c|c|}
\hline Variables & Required data & Sources of information \\
\hline \multicolumn{3}{|l|}{ Dependent variable } \\
\hline \multirow[t]{4}{*}{$\overline{\mathrm{COD}}$} & & www.hkex.com.hk (Hong Kong) \\
\hline & & Company websites \\
\hline & Finance costs & Annual report (financial statements) \\
\hline & Annual report (financial statements) & \\
\hline \multicolumn{3}{|l|}{ Independent variables } \\
\hline \multicolumn{3}{|l|}{ Test variables } \\
\hline Disclosure Score & Annual reports & Annual reports \\
\hline $\begin{array}{l}\text { Earningannouncementlag } \\
\text { Control variables }\end{array}$ & Annual reports & Annual reports (Independent Auditor's Report) \\
\hline$\overline{\text { Ln asset }}$ & Annual reports & Annual reports (financial statements) \\
\hline EVAR & 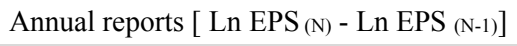 & Annual reports (financial statements) \\
\hline LOSS & Dummy variable & Annual reports (financial statements) \\
\hline
\end{tabular}

\subsection{Dependent and Independent variable}

\section{The Cost of Debt}

The dependent variable of this research is the cost of debt, which is believed to be affected by the extent of voluntary disclosure and the timeliness of earnings announcement. Cost of debt is the effective interest paid by a company. It is defined as the interest expenses for firm $i$ and year $t$ divided by the short term and long term liabilities at the beginning of year $t$ for firm I (Sengupta, 1998; Orens et al., 2010).

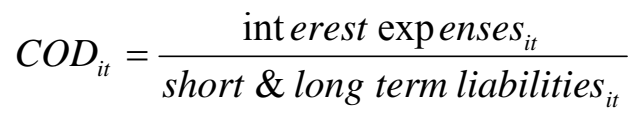

\section{Voluntary disclosure score}

A coding instrument methodology is used to measure the extent of voluntary disclosure score in companies' annual reports. Since our study examines firms listed on the Hong Kong stock exchange, we a disclosure index specifically developed by Gray and Chau (2002) for this setting. Our voluntary disclosure index incorporates twelve categories dealing with (1) general corporate information, (2) corporate strategy, (3) acquisitions and disposals, (4) research and development, (5) future prospects (6) information about directors, (7) employee information, (8) social policy and value-added information (9) segmental information, (10) financial review, (11) foreign currency information and, (12) stock price information (see Appendix 1). Each item scores "one" if the information required is presented in the annual reports, and "zero" otherwise. The overall voluntary disclosure score represents the summation of its components (Cooke, 1992). The highest score that company can get is equal to the total number of items expected to be disclosed which 113. (see Appendix 1).

\section{Earnings announcement lag}

The difference between the fiscal year end and the publication date of financial statement is selected to be a proxy for the earnings announcement lag (Lee et al., 2008). All listed companies in HKSE are subject to external auditing. Publication date is approximated by the date of issuance of the audit report (signature of the report). This date is a good proxy because companies will not delay the publication of 
their financial reports after the financial statements have been audited (Leventis \& Owusu-Ansah, 2006).

\subsection{Control variables}

Three variables are considered in this study and which are supposed to have correlation with cost of debt: Size, loss and volatility of earnings. Previous research showed that size has an impact on disclosure and therefore it might affect the cost of debt incurred by firms. Large firms are often subject to more disclosure as they have more analysts following than small firms (Lung \& Lundholm, 1993). Wallace and Naser (1995, p. 322) state that "size is a function of growth and the growth of a firm invariably results in a greater need for external capital and consequently a greater need for more comprehensive information". More voluntary disclosure implies less creditors' perceived risk and risk of default (Sengupta, 1998). Accordingly, corporate size has a negative effect on the cost of debt. In addition, it is expected that the cost of debt is an increasing function of earning variability as high earning variability leads to less accuracy in predicting future earnings (Orens et al., 2010). Finally, loss financial condition is expected to be associated with a higher cost of debt. For instance, negative earnings increase firm's financial stress and the likelihood of discretionary manipulations of accounting information (Brown, 2001, Orens et al., 2010).

\subsection{The research models}

To assess the empirical validity of the formulated hypotheses, the following the three examine the association between cost of debt and voluntary disclosure and earning announcement lag, the following three models are performed. The first model tests the association only for the extent of voluntary disclosure the second considers only earning reporting lag. Finally, the third model tests for the simultaneous effect of the two test variables. The models are presented below.

$$
\begin{aligned}
& \text { COD }{ }_{i t}=\alpha_{0}+\alpha_{1} \text { DSC }_{i t}+\alpha_{2} \text { EVAR }_{i t}+\alpha_{3} \text { LnAsset }_{i t}+\alpha_{4} \text { LosS }_{i t-1}+\varepsilon_{i t} \\
& C O D_{i t}=\alpha_{0}+\alpha_{1} E_{i t}+\alpha_{2} \text { EVAR }_{i t}+\alpha_{3} \text { LnAsset }_{i t}+\alpha_{4} \text { Loss }_{i t-1}+\varepsilon_{i t} \\
& C O D_{i t}=\alpha_{0}+\alpha_{1} D S C+\alpha_{2} E A L_{i t}+\alpha_{3} E_{V A R}+\alpha_{4} L_{n A s s e t}+\alpha_{5} L_{\text {oss }} \text { it }-1+\varepsilon_{i t}
\end{aligned}
$$

\begin{tabular}{|c|c|c|}
\hline \multicolumn{3}{|c|}{ Dependent and independent variable definitions and expected signs } \\
\hline Variable definition & Measures & Expected signs \\
\hline $\mathrm{COD}_{\mathrm{it}}$ & $\begin{array}{l}\text { The cost of debt is measured using the rate of interest paid measured as the } \\
\text { interest expenses for year } t \text { and firm i scaled by the short term and long term } \\
\text { financial debt at the beginning of year } t \text { for firm i }\end{array}$ & \\
\hline $\mathrm{EAL}_{\text {it }}$ & $\begin{array}{l}\text { Earning announcement lag is proxied by the difference between the fiscal year } \\
\text { end and the publication date of financial statement. The latter is measured by the } \\
\text { date of signature of independent auditor's report }\end{array}$ & + \\
\hline $\mathrm{DSC}_{\text {it }}$ & Voluntary Disclosure Score from each company (Gray and Chau ,2002) & - \\
\hline EVAR $_{\text {it }}$ & The variability of earnings: [Ln EPS $(\mathrm{N})-$ Ln EPS $(\mathrm{N}-1)]$ & + \\
\hline Ln Asset ${ }_{i t}$ & $\operatorname{Ln}$ (total assets) is the proxy of the firm size & - \\
\hline $\operatorname{Loss}_{\mathrm{it}-1}$ & A dummy variable, 1 if the firm in the fiscal year end is profitable and 0 otherwise & + \\
\hline
\end{tabular}

\section{Results}

\subsection{Descriptive statistics and univariate analysis}

Table 3 displays the descriptive statistics and Anova tests for voluntary disclosure scores and earning announcement lag during the period of investigation. 
In this study, we used a checklist of 113 items to assess the extent of voluntary disclosure. Descriptive statistics show that the mean of voluntary disclosure score is $45.725(\mathrm{sd}=11.542)$ which is relatively low. The average of timely disclosure, as proxied by earnings announcement lag, amounts to 96.325 $(\mathrm{sd}=50.915)$. The mean of cost of debt is $0.196(\mathrm{sd}=0.574)$. Voluntary disclosure score witnesses a slight increase during the period of investigation moving from 44.900 for 2008 and 48.200 for 2011. However, earnings announcement lag disclosure witnesses a significant decrease during the same period moving from 123.950 in 2008 to 82.300 in 2011.

Table 3

Descriptive statistics

\begin{tabular}{|c|c|c|c|c|c|}
\hline & & Number of observations & Mean & \multicolumn{2}{|c|}{ Standard Deviation } \\
\hline \multicolumn{2}{|r|}{$\mathrm{DSC}$} & 80 & 45,725 & \multicolumn{2}{|c|}{11.542} \\
\hline \multicolumn{2}{|r|}{ EAL } & 80 & 96,325 & \multicolumn{2}{|c|}{50,918} \\
\hline & $\mathrm{COD}$ & 80 & 0,196 & \multicolumn{2}{|c|}{0,574} \\
\hline \multicolumn{6}{|c|}{ Anova } \\
\hline & Category & Number of observations & Mean & Standard Deviation & $\begin{array}{c}\text { F-Statistic } \\
\text { (p-value) }\end{array}$ \\
\hline \multirow{4}{*}{$\begin{array}{c}\text { DSC } \\
\text { (Hong } \\
\text { Kong) }\end{array}$} & 2008 & 20 & 44.900 & 11.683 & \multirow{4}{*}{$\begin{array}{c}0.60 \\
(0.619)\end{array}$} \\
\hline & 2009 & 20 & 46.300 & 13.278 & \\
\hline & 2010 & 20 & 43.500 & 10.792 & \\
\hline & 2011 & 20 & 48.200 & 10.581 & \\
\hline \multirow{4}{*}{$\begin{array}{l}\text { EAL } \\
\text { (Hong } \\
\text { Kong) }\end{array}$} & 2008 & 20 & 123.950 & 92.156 & \multirow{4}{*}{$\begin{array}{l}0,293 * * \\
(0,039)\end{array}$} \\
\hline & 2009 & 20 & 91.600 & 23.297 & \\
\hline & 2010 & 20 & 84.450 & 21.777 & \\
\hline & 2011 & 20 & 82.300 & 12.393 & \\
\hline
\end{tabular}

Notes: Significant at: $*(p<0.10) ; * *(p<0.05) ; * *(p<0.01)$; COD: cost of debt; DSC: voluntary disclosure score; EAL: earning announcement lag.

In order to better analyze the relationship between these variables, we run a Pearson correlation (Table 4). Cost of debt is negatively related to voluntary disclosure score, while earnings announcement lag is positively associated with cost of debt with two means correlation amounting to (-0.340) and (0.152) respectively. These results provide support for $\mathrm{H}_{1}$ suggesting that the extent of voluntary disclosure reduces the cost of debt in Hong Kong context. Also, $\mathrm{H}_{2}$ is supported since earnings announcement lag significantly influences creditors' decisions in Hong Kong context.

\section{Table 4}

Pearson correlation coefficients for continuous variables

Hong Kong (80 observations)

\begin{tabular}{lccccc}
\hline & DSC & EAL & EVAR & LOSS & Ln (asset) \\
\hline COD & $-0.340^{* * *}$ & -0.182 & 0.058 & $0.134^{*}$ & -0.098 \\
DSC & 1.000 & $0.152^{*}$ & -0.023 & -0.034 & 0.066 \\
EAL & & 1.000 & -0.071 & 0.040 & 0.024 \\
EVAR & & 1.000 & 0.031 & 0.020 \\
LOSS & & & 1.000 & $-0.151^{* *}$ \\
Ln (asset) & & & & & 1.000 \\
\hline
\end{tabular}

Notes: Significant at: $*(\mathrm{p}<0.10) ; * *(\mathrm{p}<0.05) ; * *(\mathrm{p}<0.01)$; COD: cost of debt; DSC: voluntary disclosure score; EAL: earning announcement lag; EVAR; earning variability; LOSS: dummy variable 1 if the firm reports a negative earning and 0 otherwise; Ln (asset): corporate size as proxied by the natural logarithm of total assets.

\subsection{Multivariate analysis}

Multiple regression results are reported in table 5. Findings show that there is a negative and significant relation between the extent of voluntary disclosure and the cost of debt $(-0.016 ; t$-statistic $=-2.86)$, which is in line with the previous findings of Sengupta (2004). This negative association is also valid when we consider both earning announcement lag and the extent of voluntary disclosure on cost of debt in the same model $(-0.015 ; t$-statistic $=-2.10)$. The findings support the first hypotheses of this research 
which suggests that there is a negative association between the cost of debt bear by companies and the level of voluntary disclosure. Non-mandatory information will reduce agency problems between management and the creditors. Therefore, lenders will provide funding for those companies who provide more information to reduce the information gap. With regard to earnings announcement, results also are indicative of a positive association between the cost of debt and the timeliness of earnings announcement $(0.002$; $t$-statistic $=1.74)$. Therefore, $\mathrm{H}_{2}$ is supported since the association is positive and significant between the two variables. Therefore, timely disclosure reduces the cost of debt. Concerning the control variables, the associations reported are in line with our expectations since corporate size is negatively associated with cost of debt and LOSS variable and earning variability are positively associated with cost of debt. However, these relationships are not significant. Overall, our results provide evidence that increasing voluntary disclosure in annual reports contributes to the reduction of cost of debt. Furthermore, timely communication of information in annual reports reduces the cost of debt on Hong Kong Stock exchange. More details are provided in Table 5.

Table 5

Multiple regression analyses

\begin{tabular}{|c|c|c|c|}
\hline & $\begin{array}{c}\text { Model I } \\
\text { (Earning announcement lag) } \\
\end{array}$ & Model II (Disclosure Score) & $\begin{array}{c}\text { Model III } \\
\text { (Earnings announcement lag\& Disclosure } \\
\text { Score) }\end{array}$ \\
\hline & Hong Kong & Hong Kong & Hong Kong \\
\hline \multirow{2}{*}{ Intercept } & 0.698 & 1.087 & 1.025 \\
\hline & $(2.19)$ & $(3.24)$ & $(2.52)$ \\
\hline \multirow{2}{*}{ DSC } & & $-0.016 * *$ & $-0.015 * *$ \\
\hline & & $(-2.86)$ & $(-2.10)$ \\
\hline \multirow{2}{*}{ EVAR } & 0.010 & 0.012 & 0.012 \\
\hline & $(0.26)$ & $(0.33)$ & $(0.64)$ \\
\hline \multirow{2}{*}{ LOSS } & 0.119 & 0.150 & 0.169 \\
\hline & $(0.74)$ & $(0.96)$ & $(0.87)$ \\
\hline \multirow{2}{*}{ Ln (asset) } & -0.435 & -0.020 & -0.014 \\
\hline & $(-1.40)$ & $(-0.66)$ & $(-1.10)$ \\
\hline \multirow{2}{*}{ EAL } & $0.002 *$ & & -0.001 \\
\hline & $(1.74)$ & & $(-0.82)$ \\
\hline \multirow{2}{*}{2009} & 0.067 & -0.138 & 0.129 \\
\hline & $(0.37)$ & $(-0.77)$ & $(0.71)$ \\
\hline \multirow{2}{*}{2010} & 0.877 & 0.020 & 0.109 \\
\hline & $(0.48)$ & $(0.12)$ & $(0.80)$ \\
\hline \multirow{2}{*}{2011} & 0.001 & -0.001 & 0.106 \\
\hline & $(0.01)$ & $(-0.01)$ & $(0.95)$ \\
\hline \# of Obs. & 80 & 80 & 80 \\
\hline Adj-R-Square & 9.03 & 6.63 & 6.71 \\
\hline \multirow{2}{*}{$\mathrm{F}$ (p-value) } & 1.020 & 1.800 & 0.790 \\
\hline & $(0.4244)$ & $(0.1001)$ & 0.6106 \\
\hline Max Vif & 1.68 & 1.68 & 1.66 \\
\hline
\end{tabular}

Notes: Significant at: * $(\mathrm{p}<0,10) ; * *(\mathrm{p}<0,05) ; * * *(\mathrm{p}<0,01)$; cost of debt; DSC: voluntary disclosure score; EAL: earning announcement lag; EVAR; earning variability; LOSS: dummy variable 1 if the firm reports a negative earning and 0 otherwise; Ln (asset): corporate size as proxied by the natural logarithm of total assets. T-statistics are reported between parentheses.

\section{Concluding remarks}

The question of whether voluntary disclosure and earnings announcement lag influences cost of debt is an important issue for managers and creditors. The main objective of this study was to empirically examine the relationship between voluntary and earning announcement lag and cost of debt in the context of Hong Kong, example of vibrant developing economy in Asia. Results show that voluntary disclosure information reduces cost of debt. Also, earning announcement lag exert a significant effect on creditors' behavior in Hong Kong context. Accordingly, voluntary disclosure and timely communication of annual reports in Hong Kong play an important role in determining creditors' policy. 
Overall, our study contributes to the existing accounting literature dealing with the effects of disclosure policy on the cost of debt by providing preliminary evidences in developing economy. Results also have policy implications for managers in Hong Kong context and other developing economies similar to Hong Kong given the crucial role of debt financing as an important source of external finance in this setting. As with any empirical work, this study has some limitations. On the one hand, the limited number of companies included in the analysis could reduce the validity of the findings and inferences. Nevertheless, several empirical studies have used small sample sizes especially in Anglo-Saxon contexts (Sengupta, 1998; Botosan, 1997). On the other hand, self constructed voluntary disclosure checklist has the disadvantages to be difficult to replicate since the researcher may generally use his judgement during the coding process which can also bias the results. Therefore, findings should be interpreted with cautions.

Future research could address the same issue in other Asian markets and could also assess the association between other aspects of voluntary disclosure such as corporate governance and the cost of debt capital. In addition, examining the association between timely and voluntary disclosures and cost of equity capital in other Asian markets represents an important research topic.

\section{References}

Akerlof, G.A. (1970). The market for lemons: Quality uncertainty and the market mechanism. Quarterly Journal of Economics, 84, 488-500.

Anil and Jonathan. (2003). Are unmanaged earnings always better for shareholders?. Accounting Horizons, 17, 55-82.

Armitage, S., \&Marston, C. (2007), Corporate disclosure and the cost of capital: the views of finance directors. http://www.icaew.com/ /media/Files/Technical/Research-and-academics/publicationsand-projects/financial-reporting-publications/briefing-corporate-disclosure-and-the-cost-ofcapital.pdf.

Begley, J., \& Fischer, P. (1998). Is there information in an earnings announcement delay? Review of Accounting Studies, 3(4), 347-36

Bhojraj, S., \& Sengupta, P. (2003). Effect of corporate governance on bond ratings and yields: The role of institutional investors and outside directors. The Journal of Business, 76 (3), 455-476.

Blanchet, J. (2002). Global standards offer opportunity. Financial Executive, 18, 28-30.

Botosan, C. (1997). Disclosure level and the cost of equity capital. The Accounting Review, 72 (3), 323 349.

Bowrin, R. (2008). International accounting standards and financial reporting quality in Trinidad and Tobago. Business, finance and economics in emerging economies, 3 (1), 119-150.

Brown, L. (2001). A temporal analysis of earnings surprises: profits versus losses. Journal of Accounting Research, 39 (2), 221-41.

Chambers, A., \& Penman, P. (1984). Timeliness of reporting and the stock price reaction to earnings announcements. Journal of Accounting Research, 22, 21-44.

Chau, G.K., \& Gray, S.J. (2002). Ownership structure and corporate voluntary disclosure in Hong Kong and Singapore. The International Journal of Accounting, 37 (2), 247-264.

Cooke, T. E. (1989). Disclosure in the corporate annual reports of Swedish companies. Accounting and Business Research, 19 (74), 113-124.

Cooke, T.E. (1992). The impact of size, stock market listing and industry type on disclosure in the annual reports of Japanese Listed Companies. Accounting and Business Research, 22, (87), 229237.

Dadashi, I., Zarei, S., Dadashi, B., \& Ahmadlou, Z. (2013). Information voluntary disclosure and cost of debt case of Iran. International Research Journal of Applied and Basic Sciences, 4 (6), 14781483.

Diamond, D. and Verrecchia, R. (1991). 'Disclosure, liquidity and the cost of capital'. The Journal of Finance, 46 (1), 325-360. 
Entwistle, G. M., \& Phillips, F. (2003). Relevance, reliability, and the earnings quality debate. Issues in Accounting Education, 18(1), 79-92.

Epstein, M.J., \& Birchard, B. (2000). Counting what counts: Turning corporate accountability to competitive advantage. Perseus Books, Cambridge, MA.

Healy, P., \& Palepu, K., (2001). A review of the empirical disclosure literature. Journal of Accounting \& Economics, 31, 405-440.

Jang and Tang. (2003). The Profitability of the Banking Sector in Hong Kong. Hong Kong Monetary Authority Quarterly Bulletin.

Jensen, M.C., \& Meckling, W.H. (1976). Theory of the firm: managerial behaviour, agency costs and ownership structure. Journal of Financial Economics, 3 (4), 305-360.

Klai, N., \& Omri, A. (2011). Corporate governance and financial reporting quality: The case of Tunisian firms. International Business Research, 4(1), 158-166.

Kulzick, R. S. (2004). Sarbanes-Oxley: Effects on financial transparency. Advanced Management Journal, 69, 43-49.

Lang, M. H., \& Lundholm, R. J. (1993). Cross-sectional determinants of analyst ratings of corporate disclosures. Journal of Accounting Research, 31, (2), 246-271.

Lee, H. Y., Mande, V., \& Son, M. (2008). A comparison of reporting lags of multinational and domestic firms. Journal of International Financial Management \& Accounting, 19(1), 28-56.

Meek, G. C., Roberts, B., \& Gray, J. (1995). Factors influencing voluntary annual report disclosures by U.S., U.K. and Continental European multinational corporations. Journal of International Business Studies, 26 (3), 555-572.

Meek, G.K., \& Gray, S.J. (1989). Globalization of stock markets and foreign listing requirements: Voluntary disclosures by continental European companies listed on the London Stock Exchange. Journal of International Business Studies, 20(2), 315-338.

Orens, R., Aerts, W., \& Cormier, D. (2010). Web-based non-financial disclosure and the cost of finance. Journal of Business Finance and Accounting, 37(8-9), 1057-1093.

Owusu-Ansah S., \& Leventis, S. (2006). Timeliness of corporate annual financial reporting in Greece. European Accounting Review, 15 (2), 273-283.

Sengupta, P. (1998). Corporate disclosure quality and the cost of debt. The Accounting Review, 73 (4), 459-474.

Sengupta, P. (2004). Disclosure timing: Determinants of the quarterly earnings release dates. Journal of Accounting and Public Policy, 23, 457-82.

Wallace, R.S.O., Naser, K., \& Mora, A. (1994). The relationship between the comprehensiveness of corporate annual reports and firm characteristics in Spain. Accounting and Business Research, 25 (97), 41-53.

Wang, K., O, S., \& Claiborne, M.C. (2008). Determinants and consequences of voluntary disclosure in an emerging market: Evidence from China. Journal of International Accounting, Auditing and Taxation, 17, 14-30

\section{Appendix 1.}

Voluntary Disclosure checklist

\begin{tabular}{|c|c|}
\hline Category of information & Items of disclosure \\
\hline \multirow[t]{2}{*}{ 1. General corporate information } & a. Brief history of company \\
\hline & b. Organisational structure \\
\hline \multirow[t]{2}{*}{ 2. Corporate strategy } & a. Statement of strategy and objectives-general \\
\hline & b. Statement of strategy and objectives-financial \\
\hline \multirow[t]{2}{*}{ 3. Acquisitions and disposals } & c. Statement of strategy and objectives-marketing \\
\hline & d. Statement of strategy and objectives-social \\
\hline \multirow[t]{2}{*}{ 4. Research and development } & e. Impact of strategy on current results \\
\hline & f. Impact of strategy on future results \\
\hline \multirow{4}{*}{ 5. Future prospects } & a. Reasons for the acquisitions \\
\hline & b. Amount of goodwill on acquisition \\
\hline & c. Reasons for the disposals \\
\hline & d. Amount of consideration realised from the disposal \\
\hline \multirow{4}{*}{ 6. Information about directors } & a. Description of R\&D projects \\
\hline & b. Corporate policy on R\&D \\
\hline & c. Location of R\&D activities \\
\hline & d. Number employed in R\&D \\
\hline
\end{tabular}


7. Employee information

8. Social policy and value-added information

9. Segmental information b. Qualitative forecast of sales

c. Quantitative forecast of sales

d. Qualitative forecast of profits

e. Quantitative forecast of profits

f. Description of capital project committed

g. Committed expenditure for capital projects

h. Qualitative forecast of cash flows

i. Quantitative forecast of cash flows

j. Assumptions underlying the forecasts

k.Ordrer book or backlog information

a. Age of the directors

b. Commercial experience of the nonexecutive directors

c. Educational qualifications

d. Commercial experience of the executive directors

e. Other directorships held by nonexecutive directors

f. Other directorships held by executive directors

g. Position or office held by executive directors

a. Geographical distribution of employees

b. Line-of-business distribution of employees

c. Categories of employees by sex

d. Identification of senior management and their functions

e. Categories of employees by function

f. Number of employees for 2 or more years

g. Reasons for changes in employee numbers or categories over time

h. Share option schemes-policy

i. Profit sharing schemes-policy

j. Amount spent in training

k. Nature of training

1. Policy on training

10. Financial review

$\mathrm{m}$. Categories of employees trained

n. Number of employees trained

o. Welfare information

p. Safety information

q. Data on accidents

r. Cost of safety measures

s. Policy on communication

t. Redundancy information

11. Foreign currency information

u. Equal opportunity policy statement

v. Recruitment problems and related policy

a. Safety of products

b. Environmental protection programs - qualitative

c. Environmental protection programs - quantitative

d. Charitable donations

e. Community programs

f. Value-added statement

g. Value-added data

h. Value added ratios

i. Qualitative value-added information

a. Geographical capital expenditure-quantitative

b. Geographical net assets-quantitative

c. Geographical production-quantitative

d. Line -of- business capital expenditure-quantitative

e. Line-of-business net assets-quantitative

f. Line-of-business production-quantitative

g. Competitor analysis-qualitative

h. Competitor analysis-quantitative

i. Market share analysis-qualitative

j. Market share analysis-quantitative

a. Profitability ratios

b. Qualitative comments on profitability

c. Cash flow statement- direct

d. Cash flow ratios

e. Liquidity ratios

f. Gearing ratios

g. Fixed asset revaluation within the last 5 years

h. Disclosure of brand valuation

i. Disclosure of other intangible valuations (expect goodwill)

j. Dividend payout policy

k. Transfer pricing policy

1. Impact of any accounting policy changes on results

$\mathrm{m}$. Financial history or summary-3 or more years

n. Financial history or summary- 6 or more years

o. Restatement of financial information to IASC

p. Off balance sheet financing information

q. Advertising information-qualitative

r. Effects of inflation on future operations-qualitative

s. Advertising expenditure-quantitative

t. Effects of inflation on results-qualitative

u. Effects of inflations on results-quantitative

v. Effects of inflations on results-qualitative

w. Effects of inflation on assets-quantitative

$x$. Effects of interest rates on results

y. Effects of interest rates on future operations 
a. Effects of foreign currency fluctuations on future operations-qualitative

b. Effects of foreign currency fluctuations on current results-qualitative

c. Major exchange rates used in the accounts

d. Long-term debt by currency

e. Short-term debt by currency

f. Foreign currency exposure management description

a. Share price at year end

b. Share price trend

c. Market capitalization at year end

d. Market capitalization trend

e. Size of shareholder

f. Type of shareholder

g. Foreign stock market listing information 